\title{
Evolutionism and Common Sense. Notes on the History of Biology
}

António B. Vieira

FCSH-UNL/CFCUL vieyrantonio@hotmail.com

DOI 10.1515/kjps-2017-0009

\section{Animal-machine and Animal-homunculus}

Unable to find clear operational criteria for defining man, I have formerly chosen to characterise it thus: man is the only primate who guides his behaviour by prejudice. Now, one of the areas of human knowledge, science, proposes to reflect critically on its own validity according to demonstrable objectifying criteria, often quantifiable as well as open to refutation. Even the fabric of science, however, seeps prejudice, and temporary constructions (models and theories) that guide scientific research are open, in certain sensitive points, to manipulation and distortion aimed at another critical device - the common sense.

Under the guise of indifferent bonhomie, common sense reflects a trend of beliefs, which in a given cultural and historical context, take hold of partial, simple and seductive fragments of knowledge. Science proceeds a posteriori, following the renewed current of knowledge; common sense proceeds a priori, according to beliefs, desires and intuitions at the service of projects (religious, moral, ideological, utopian) which have always been intended to establish arbitrary power relations, opposed to the Enlightenment. This attitude disregards the testing procedure in the 
context of the articulated unity of science. It prefers, instead, to proceed by isolated segments of knowledge, operating on the simplified interpretations of these islands of information, while ignoring the complex and provisional findings that a true heuristic work would later perfect. Thus, between science and common sense - and despite the mutually exerted influences - opens a wide gap, which corresponds to the distinction between a knowledge that is never final, and a conjecture that is taken as reality.

It is appropriate, at this point, to survey the evolution of the concepts throughout the history of biological thought. At least since the Classical Age, and contrary to the expectations of the evolutionary model of Thomas Kuhn (1970), (non-human) animals have been regarded and interpreted either as mechanisms, or as homunculi (imperfect men, partial, unfinished, immature). These two sides have been present in the history of zoology (itself plaited with the general history of ideas and the history of medicine) as the two sides of the Möbius' strip. Either one of them - the animal-machine and the animal-homunculus - is accessible to common sense and, at the same time, open to a wise assessment of nature. Montaigne regarded animals as partial men, admitting that "ils ont un discours au dedans qui les rend aussi disciplinables et volontaires à apprendre" (they possess an inner discourse that makes them tameable and willing to learn) (Essais, II: XII).

For Descartes, on the other hand, animal non agit, agitur, "the animal does not act, it is acted upon" (Discours de la méthode, V), and this is the view held by Malebranche. In the 18th century, when the essence of animal behaviour was not just scrutinised by philosophers but by naturalists, the conflicting paradigms persisted: Linné stressed the animal-machine, Buffon the animal-homunculus. "Sans l'existence des animaux", he writes, "I'homme serait encore plus incompréhensible". (Without the existence of animals, man would be even harder to understand). And Condillac, in his Traité des sensations, appeared in 1754, admits that animals can have representations and even communicate by means of some kind of language without words (Condillac, 1984). But soon Cuvier resumes, under a different perspective, the Cartesian view. "Cuvier had such an exalted concept of the perfection of the correlation of parts that 
this was one of the major reasons why he could not conceive of any evolutionary change". (Mayr, 1982, p. 461).

When Lamarck, after his inaugural lecture on the 21 Florival of year VIII of the Revolution (March 11, 1800) - the Discours d'ouverture (Lamarck, 1807) - began teaching the evolution of all living beings as a continuum, a scala naturae, he accepted that the changes were operated and guided by an "adaptive conscience" ingrained within each organism'. Man being the last and the most developed stage of the Lamarckian chain, all other species shared a part of man's nature. The very long title of Lamarck's key work, which I transcribe below, hinted already at this conclusion: "Philosophie zoologique, ou Exposition des considérations relatives à l'histoire naturelle des Animaux; à la diversité de leur organisation et des facultés qu'ils en obtiennent; aux causes physiques qui maintiennent en eux la vie et donnent lieu aux mouvements qu'ils exécutent; enfin, à celles qui produisent, les unes le sentiment, et les autres l'intelligence de ceux qui en sont doués".

With Darwin, from the publication in 1859 of The Origin of the Species by Means of Natural Selection, Lamarck's gradualist transformism, open to common sense, gave way to a more complex evolutionary mechanism, less accessible to ordinary understanding. In certain points, however, still very close to Lamarck's ideas (since Darwin did not have the basis for a grounded theory of heredity), Darwin stressed the animal-homunculus. This can be seen in the titles of the chapters and additions to the second edition of The Descent of Man, a book published in 1871, marking the motivational affinity between man and other animals. Thus: "Intelligence in a baboon", "Sense of humour in dogs", "Reasoning power in the lower animals", "Power of abstraction in animals". The concept of natural selection leans toward the animal-machine trend, while the concept of sexual selection (which Darwin compares with artificial selection, intentionally directed) leans toward the animal-subhuman pole.

Already the hyperseleccionist Alfred Russel Wallace (Gould, 1985) was an advocate of the animal-machine, and that was also the position of

\footnotetext{
1 A few years earlier, Kant, in the second part of his Critique of Judgment had outlined an evolutionist project of living beings, comparing a democratic state to a living body, and a despotic state to a machine.
} 
August Weissmann, with his theory of "germ plasm". Those close to Darwin had differing views; Romanes defended the intelligence of animals, while Lloyd Morgan excluded any conscious factor of causation of behaviour (in Thorpe, 1979). At the beginning of the 20th century, after the rediscovery of Mendel's monograph, which finally brought the material basis for a theory of genetics, Hugo de Vries' saltationism ${ }^{2}$ and Loeb's theory of tropisms returned to the mechanical pole of the living beings; while Jennings postulated some form of memory and consciousness even in protozoa (Jennings, 1927).

Later, when behaviourists dissociated a narrow behavioural segment of the animal-machine, which they took for a model and paradigm to demonstrate an elementary system of learning, the Gestalt psychologists attributed to animals decisions and choices motivated by preferential stimuli. While William McDougall argued for his purposive psychology, of vitalist foundation, D'Arcy Thompson adopted a late-Pythagorean view, assuming the gradual transforming action of physical and geometrical forces acting on the morphological plan of each taxon, and extracting from it the configurations of each species, thus returning to the animal-machine (Thompson, 1961).

Meanwhile, Jacob von Uexküll demonstrated the sensory singularities of each species and indicated the position of each animal in their own world (Uexküll 1921). Though remaining a vitalist, he removed himself from the whole of the evolutionary scientific community. Von Uexküll was a researcher of the animal in its habitat, as well as a scrutiniser of the psychology of differently developed and complex species. He held, speaking of the tick Ixodes trianguliceps (one of the animals whose functional cycle he elucidated): "this living being is a subject, who lives in its own world, of which it is the centre. One cannot, therefore, compare it to a machine, but to the project that drives the machine. (...) There is no portion of the body of the tick that resembles a machine, nevertheless, in all its parts there is a mechanism in action". (Uexküll, op. cit.).

$2 \quad$ Diverging from the gradualist model of evolution proposed by Darwin, De Vries admitted, based on an erroneous observation made in plants, that the formation of new species took place from macro-mutants, and that it operated on a single generation's time (speciation by sudden jumps). 
In the 70s, the sociobiology of Edward Osborn Wilson reemphasised the animal-machine, with the "machine" comprising whole societies of animals - Wilson focused, mostly, on highly gregarious social insects, Isoptera (termites) and Hymenoptera (bees, wasps, ants). Later, he extrapolated his findings to human societies, being harshly criticised for epistemological incorrectness. The sociobiological model had yet another kind of complicity with common sense, by being compliant with the neoliberal society, which, in a way, it vouched for and announced. According to this view, the organisms are vehicles to spread and multiply genes, in analogy with the neoliberal societies, where human beings are vehicles to spread and multiply the capital.

The dichotomy established by Wilhelm Dilthey between natural sciences (focused on explanation and external observation) and human sciences (built on understanding and interiority, by co-empathy) helps us understanding the grounds for this long-lasting controversy, though it fails to solve it since, once again, it separates man from the remaining species. The fracture between sciences turned to the exterior and sciences focused on inner search does not question the unity of nature; it questions, rather, the necessary method to approach it in all its boundaries.

The objectivist ethology of Karl von Frisch, Konrad Lorenz, and Nicolaas Tinbergen, aware of the behaviour of animals in their environment, soon distinguished the strict programmes and areas of learning, which were always manifest in each studied species (Lorenz, 1981). Let us hear one of the founders of ethology, William Thorpe: "It is true that science must always be objective. However, when we study living animals, who are, to some extent, similar to us, it is always salutary to put ourselves in their place, in our minds, considering what would we do under the same circumstances". (Thorpe, op. cit.). Finally, the great theoretician Ernst Mayr proposed a clarifying model, by considering the greater or smaller openness of programs of each animal species to a certain degree of learning, from information encoded in the genome (Mayr, 1976). In this way, each species receives by phylogenetic inheritance a set of more or less rigid behavioural equipment, whose degree of modulation itself is genetically programmed. 
The curious historical dichotomy between innate and acquired knowledge has livened up the epistemological and ideological debate between innateness and constructivism, which took the dimensions of an extensive controversy and reached its peak in the $60 \mathrm{~s}$ and the $70 \mathrm{~s}$ of the 20th century. Man and human societies were the target of this discussion; the reliability of the method was its pretext. Those promoting the philosophies of history before its decline showed preference for a "behaviourist" man, susceptible to radical change by absorbing and mimicking a doctrine, in order to thus alter the texture of society in a few generations' time (without realising that human mimicry was a phylogenetic trait, with deep and frightful historical consequences): the postulate of a residue of any kind of fixed behavioural pattern was supposed to hinder such optimism.

The famous Royaumont encounters in the 70s and 80 s confronted the positions, arguments and language of the innatists, amongst which was Chomsky, and those of the constructivists, which included Piaget (Piattelli-Palmarini, 1979). In fact, the work of the latter, conducted with children of different ages, and considered by some an example of elegance and rigour, was refuted at a later point, as it did not account for the influence of mimic interactions between the researcher and the subject (e.g. at the moment when the subject had to choose between two options before the eyes of a researcher who, from the start, preferred one of the alternatives). Here we have how the nonverbal expression of behaviour - the role of expressive mimicry in communication - can distort the accuracy of an experiment that depends on the interaction of human beings, leading to the so-called rosenthalization of results. This designation derives from the name of the psychologist Robert Rosenthal, who devoted himself to prove the role of nonverbal communication in the interpersonal mediation of the effects of expectation.

\section{The Synthetic Theory of Evolution}

Nothing is more foreign to common sense than the idea of variational evolution and natural selection. Stephen Gould shows us the debris of the wreck of common sense against the Darwinist theory of evolution, and its appeal under Lamarck's shadow: "I suspect a more important reason for 
Lamarckism's continuing appeal lies in its offer of some comfort against a universe devoid of intrinsic meaning for our lives. It reinforces two of our deepest prejudices - our belief that effort should be rewarded and our hope for an inherently purposeful and progressive world" (Gould, 1980, p. 70).

"There is in Lamarckism a fundamental optimism (...) that man and societies are mouldable entities subject to rapid improvement by educational actions and consequential transformations on the individual or the group" (Sacarrão, 1989, vol. II, p. 300). For this order of reasons, the fake scientists Mitchurine and Lysenko, with the protection of the State, imposed on the Soviet Union's farming in the 40s a neo-Lamarckian orientation ultimately aimed at obtaining "the new man". Denounced by Lysenko, the respected researcher Nikolai Vavilov was arrested in 1940 and was murdered in prison. Meanwhile, under the new momentum, the country's economy collapsed, and hunger spread, annihilating millions of people, especially in the Ukraine. In the following decade, an analogous experience was imposed in China, with the same catastrophic results (Sacarrão, op. cit.).

In fact, the man guided by common sense sees evolution according to the references of his own life: effort, rigour, and obedience guide his more or less successful progression, and will, tempered by experience, guide his learning. He who does not have his critical judgment poisoned by the biblical and fixist prejudice ${ }^{3}$ (nothing prevents that, ultimately, one believes that the Earth is flat, going back to Aristotle, and giving his senses the joy of reproducing immediately the shape of his beliefs) will find it easier to empathise with the intuitive arguments of Lamarck, than with the one long argument with which Darwin qualified his theory.

But there is an additional reason of irresistible appeal: the ascending and teleological character of the Lamarckian construct, which encapsulates the collective impulse of will, of necessity and of hope (longing for perfection). It is the idea of a path towards a goal defined along the way,

3 Up to this day, Jewish and Orthodox Christian groups, and the whole of the Muslim States hide, against all evidence, the reality of evolutionism, wanting, in many cases, to forbid its teaching and to censor its propagation. Such attitude, opposed to the ideas of the Enlightenment, can only arise from ignorance or bad faith. 
and the confusion between evolution and progress: man (under his only form known at the time, Homo sapiens Linée) becomes the destiny and the end point of evolution. All Lamarckians have cherished the nostalgia of this ruée vers l'homme ("a race towards man"), which, for believers, approaches the "omega point" of the design of Teilhard de Chardin (for an assessment of the meaning of his work, cf. Vieira, 2005).

In reality, man, either in the form of the current species, or in the form of his extinct species - i.e. including the paleospecies and the genus given by the taxonomists - is in the biosphere thanks to a random and opportunistic accident. Hominins appeared about more or less six million years before present. Homo sapiens has been around only very recentlyaround 200,000 years before the present day - and the extreme openness of his programme, that natural selection has provided him, does not augur a long stay. Evolution abides to the principle of "evolutionary opportunism" (Dobzhansky, 1970) and proceeds as a result of unpredictable variations of environment. Moreover, the invention of evolutionary solutions lies in error - error in the replication of DNA, the very origin of mutations.

No a priori purpose guides the evolution of the species. The Synthetic Theory of Evolution, which integrated the model of Darwin and population genetics (Ronald Fischer, Sanderson Haldane, Sewall Wright, Sergei Chetverikov), opened a large multidisciplinary research programme that answers the "how" and the "why" of the evolutionary mechanism of the living, though without saying anything on the "what for". All this disappoints the man of common sense, who likes to be cradled in nationalistic or historical triumphalism, sometimes, even in scatological utopias, giving meaning to his presence in the world and a reward to his destiny. Common sense only understands one of the stages of the selection process - that of necessity - not being able to conceive of the role of chance, borrowing two words from the famous book by Jacques Monod, Le hasard et la nécessité (Monod, 1970).

After all, the pre-historical populations who started the domestication of some animal and plant species, changing the means of production of human groups and inaugurating the Neolithic period, intuited and practiced a selective form, on which, certainly, chance was absent and replaced by the "necessity" of the goal towards which the process was 
directed. This evolutionary pressure initially postulated (aimed at, for instance, extracting from the wild wolf less feral strains, or making wild livestock less territorial and less aggressive) was denominated artificial selection. Darwin learnt of the concept and found in it a benchmark for his own theory: in nature, evolution progresses in a similar way, though the goal guiding it changes constantly, since Earth is active and the biosphere changes according to several parameters. Thus, the evolutionary target is adaptation, never concluded, since it always has to face a changing environment.

The other side of the dynamics of selection, chance, would only become possible to explain based on the works of Mendel, lost to the scientific community for several decades. Therefore, Darwin's troubles were in vain trying to come up with a theory of heredity, which, taking too long to shape, made him come closer to some of the Lamarckian postulates. Once the monograph of Gregor Mendel was found again, the basis of the laws named after their author, Darwin was no longer present. Only later, in the 30s and the 40s, did population genetics show the population key to evolution, leading to the Modern Synthesis proposed by Julian Huxley (Huxley, 1942). It was not the will of individuals, nor the advantage of the species, which led evolution towards adaptive acquisitions: what guided evolution was the variation between the individuals of a given population, within a determined environment under constant change.

Traits that seemed adaptive at a given moment or place could cease to be so in the short term (climate change, chemical or acidity changes of the soils, fauna and flora, predators and prey, parasites, vectors and hosts, etc.). Adaptive renewal is played from diversity, and the genes of the organisms better endowed regarding the new coordinates of the environment will be more represented in the following generations in the genetic pool of a given population, reaffirming by feedback the traits they convey. Therefore, when facing change, the differential reproduction of organisms responds with favourable traits, at the expense of those having maladaptive and counter-adaptive traits. In a few generations' time, a trait can be multiplied or suppressed in this way under the effect of ecological pressures affecting populations.

Thus, genetic recombination produces random formulae, always different, which arise through the combinatory process of meiosis as a cast of 
the die on the gaming table - often valuable, but not always following the rules of the game. Ultimately, it is the error of replication that results in actual novelties (new genes, new characters, possibly useful against the new external conditions). The phenotypic traits (morphological, physiological, biochemical, behavioural) resulting from a given formula of genotype are tested in the interaction with the environment, and the process subjects them to a screening that will influence the genes from one generation to the other. In other words: from chance (the score marked on the die), necessity selects the formulae more suitable for adaptation. Since adaptation is insatiable, because the environmental change is never ending, selection progresses in unpredictable directions.

Common sense clashes with this complexity, eager for linear and definitive solutions. Therefore, the prevailing view amongst the European educated classes (not the specialists) after the publication of The Origin has remained of Lamarckian flavour. This tendency was strengthened by the fact that the evolution of customs, of fashion, of values and beliefs, of language and history follows, apparently, an oriented direction, teleological, accessible to understanding and approval, just like artificial selection. "A simple and dramatic theory that explains everything makes good press, good radio, good TV, and best-selling books. Anyone with academic authority, a halfway decent writing style, and a simple and powerful idea has easy entry to the public consciousness" (Lewontin, 1993, p. vii).

Another factor disturbs the simple minds: the modifying action of selection adds occasional enhancements, step by step, to organisms whose basic morphological plan is thus modified in ways that will seem incoherent. Since the costs of a global remodelling of the pre-existing structure are huge, the bricolage is more affordable for evolution, improvising small fixes to solve small defects, than the ideal remodelling of the whole morpho-physiological plan of an organism, and selection seizes these advantages and fixates these traits. According to the beautiful metaphor of François Jacob, evolution operates not by the design of an architect, but by the less costly improvisation of a bricoleur (Jacob, 1970). Hence the so-called phylogenetic inertia: an organ that used to have a function loses its purpose and, instead of being simply suppressed in a 
given evolutionary line, shrinks and remains as a vestige. These structures are called vestigial organs.

There are numerous examples of such evanescent organs that persist without a function. The case of the coccyx is exemplary. It is a bone present in anthropoids (therefore in hominins), where the caudal vertebrae are merged - vertebrae inherited from less evolved forms of primates, whose tail was free and had important functions (prehensile, balance, communication, etc). Henceforth useless, the caudal spine was not suppressed, but it atrophied and suffered this involution. Free still in human embryos, it persists later under the form of this small bone, which is articulated with the sacrum, and in which we can clearly distinguish the bodies of four or five vertebrae and the inter-vertebral symphyses. Scarcely ever does an anomaly result in human newborns bearing a free tail (Blanchard, 1885), but even Rudolph Virchow, vicious opponent of the idea of evolution, has observed this anomaly (Testut, 1904). On its own, the human coccyx and the coccyx of the pongids, considered in terms of comparative anatomy and embryology, illustrates and proves the bases of the evolutionist thought, showing the process of bricolage that goes hand in hand with evolution. No sensible god would have invented such an organ devoid of function ${ }^{4}$.

A unifying theory of evolution must be imagined on the larger stage of nature and in the critical intersection of natural sciences. For this reason, Lamarck, a museum naturalist, had the right intuition of the dynamic unity of living beings 5 ; but it was Darwin and Wallace, seasoned travellers and multidisciplinary observers (zoology, botany, comparative anatomy, embryology, geology, fossils, biogeography) who managed to grasp the real mechanism of the process. It was this wide scope correlating data from different fields that led them to formulate the evolutionary theory based on variation, which remains inaccessible to the average man of common sense.

$4 \quad$ In fact, the coccyx still serves as attachment to some muscle fibres.

5 "Perhaps the fact that he had travelled so little was responsible for his lack of interest (in problems of geography). In this he differs strikingly from the Darwinian generation" (Mayr, 1976, p. 2229). 
The Swiss phenomenologist Ludwig Binswanger summed up the situation: "The crowd, the masses, do not learn anything, do not reflect on anything, do not know anything nor do they retain anything; they imagine, however, that they know something" (Binswanger, 1971, p. 26). Plato, in the Phaedrus, concentrated this idea in one statement: "They will appear to be omniscient and will generally know nothing". Common sense, however, sees in the science of its time the ultimate revelation of truth. Pernicious ingenuity, alas, which projects the omnipotence of the ignorant in the task of science.

How does one make he who is guided by the dictates of uncritical pragmatism admit that the natural sciences progress by the successive formulation of models, refuted and reformulated otherwise under the impact of the phenomena under observation? How can one show that, ultimately, objects remain opaque and deny us their ultimate truth? And yet, this "truth" suffers a slow and continuous approach, as the focus of an increasingly powerful microscope, every time more potent, more perfect, which spells out the hidden forms of nature without ever depleting them nor unravelling them to the end. Moreover, it is necessary to reflect on the ultimate sense of science in the light of a posthumous fragment of Nietzsche (Studienausgabe, 13: 333) according to which the foundation of science consists in applying to chaos a reading grid and in extracting from this operation not knowledge, but power.

In any case, there is in the sciences of nature a prodigious unity and coherence, which always incites new unveilings. Since the naturalists of Antiquity, biology (or what came to be called biology with Jean-Baptiste Monet, chevalier de Lamarck) resembled a dismembered Titan. Zoology, botany, geology, geography, morphology and systematics had developed side by side. Later came physiology, biological chemistry, palaeontology, embryology and many other disciplines that used to lay like disjointed pieces. Now, with the emergence of the Synthetic Theory of Evolution, the Titan was revived; the fragments of his body came together; the limbs found their proper place. Each of the newly reunited parts, restored, found its place on the whole and its raison d'être, each of them justifying the others and taking from them their own justification. Ancient and new disciplines interbreed cohesive arguments, which mutually validate one another. 
The unity of science reflected the unity of nature ${ }^{6}$, the logic of the former matching the wholeness of the other. Thus, the new evolutionist thinking, based on the descent from a common ancestor, constituted the great epistemic breakthrough in life sciences. It widened the field of research (nowadays with a huge scope, from molecular biology to social biology) but, at the same time, it was submitted to the pressure of the established powers, of tradition, of prejudice. The man of common sense, who sees with only one eye, as the Cyclops, does not grasp the breadth and the beauty of this new way of observing the world - neither the diversity of spaces nor the depth of times evoked (the geological eras).

\section{Racism, Theory and Common Sense}

As the work of science approaches the inquiry on the position of man in nature, the powerful currents of prejudice blow as a whirlwind to obscure the criteria of proof. In these problematic spaces, ideologies come into play, seeking the validation of biological models, manipulating science and disseminating, among men of common sense, these readyto-use distortions. More disturbing still, the very scientific theoreticians, contaminated by l'air du temps or by their own convictions, conceded to this complicity and extracted from it an ephemeral glory. One of the examples that run through the history of biological anthropology is the trend seeking to justify racism on theoretical grounds.

The misunderstanding at the birth of modern racism, of a pseudo-scientific brand, goes back to Darwin himself. Once the decisive arguments for his theory were collected, it seemed obvious that the human species would have, as any other species, a phylogenetic natural history. At first, Darwin hardly mentioned it. In The Origin of the Species he only makes one discreet reference to man, on the penultimate page of the book: "Much light will be thrown on the origin of man and his history". This

6 A fine example of the articulated unity of nature is given by the recent observation that dung beetles of South Africa (Scarabaeus satyrus), taxonomically related to the Egyptian sacred beetles, find orientation in their nocturnal movements - in which they roll a ball of dung where the eggs are laid - in the glow of the Milky Way. Natural selection has fixated this sign-stimulus, contained in the sensorial spectrum of the beetle and inscribed in their behaviour programme (Dacke et al., 2013). 
sentence was erased, also discreetly, from the first German edition of the essay, revealing how much it disturbed common sense in a country of Lutheran tradition. Twelve years later, Darwin dedicated part of his book The Descent of Man and Selection in Relation to Sex (Darwin, 1871) to the evolution of man.

The then scarcity of known fossils of human lineage limited the factual demonstration of the theses advanced in the book. But humanity occupied, naturally, a branch in the tree of living beings and was connected to pre-human and non-human ancestors no longer in existence. As chimpanzees and gorillas (bonobos were not yet recognised as a distinct species) were the closer relatives of man in the present, Darwin postulated that the continent where they lived, Africa, would have been the starting point of humanity, as it would be later confirmed. Lacking a compelling genetic theory and effective means of dating, he has deducted from his theory what would have been the evolutionary path between pre-human hominoids and the man of the present day. And he concluded, wrongly, that certain current human populations, on the periphery of civilisation, with their strange customs and without a writing system, represented residues of archaic populations, less evolved and doomed to disappear.

He believed, even, to have observed one such population when the Beagle sailed along the shores of Tierra del Fuego and the crew spotted the Fuegians (Vieira, 2009-2010). Thinking that the technologic backwardness of that people was due to a biological backwardness that would destine them to upcoming extinction, he has not even valued the fact that some of those Fuegians, captured and taken to England, quickly learnt English and even converted to Christianity.

Let us compare two of Darwin's texts. In the Beagle Diary under the entry of the 18th of December 1832, he wrote: "It was without exception the most curious $\&$ interesting spectacle I ever beheld. - I would not have believed how entire the difference between savage $\&$ civilised man is. - It is greater than between a wild \& domesticated animal. (...) - Their language does not deserve to be called articulate. (...) I believe if the world was searched, no lower grade of man could be found" (Darwin, 1988). And then, thirty-nine years later, in The Descent of Man, with the whole of his theory already elaborated, he wrote: "Whether primeval man, when he possessed but few arts, and those of the rudest kind, and when his 
power of language was extremely imperfect, would have deserved to be called man, must depend on the definition which we employ" (Darwin, 1871, vol. I, p. 279).

The diversity of the phenotypic and cultural aspects prevented the always watchful and serene Darwin from taking more cautious conclusions. He would hesitate, even, in concluding the taxonomic distance which separated these "residual" people from civilised populations: "In a series of forms graduating insensibly from some ape-like creature to man as he now exists, it would be impossible to fix on any definite point when the term 'man' ought to be used. But this is a matter of very little importance (...) whether the so-called races of man are thus designated, or are ranked as species or sub-species; but the latter term appears the more appropriate" (Darwin, op. cit., pp. 279-280). An amazing doubt coming from someone who had observed the Brazilian populations where Europeans, Africans and Amerindian would mix without limitation of fertility.

Surely the boundaries between species, the reproductive isolation on the basis of the very definition of species, and the speciation phenomenon, unknown to Darwin, made him think here in terms of a scala naturae. In the end, it was the universality of emotive mimicry (Darwin, 1872), which forced him to admit the unity of man beyond the diversity in appearance and the disparity of cultural behaviour.

The appropriation of Darwin's ideas, as the publications kept coming out, illustrates a gift of science to common sense. Herbert Spencer and Francis Galton applied erroneous conclusions of an incomplete theory to the Victorian ideology, and began the movement known as "social Darwinism", completely foreign to the ideas of the great scientist ${ }^{7}$. In Germany - at the same time as the fixist racism of Rudolph Virchow - Ernst Haeckel, one of the first adepts of Darwinism, outlined an evolutionist

$7 \quad$ Darwin, privately, on Spencer: "I did not like him particularly, and did not feel that I could easily have become intimate with him. I think he was extremely egotistical. (...) I am not conscious of having profited in my own books by Spencer's writings. His deductive manner of treating every subject is wholly opposed to my frame of mind. His conclusions never convince me. His fundamental generalisations (...) are of such a nature that they do not seem to me to be of any strictly scientific use. They partake more of the nature of definition than of laws of nature. (...) Anyhow they have not been of any use to me" (Barlow, 1958, pp. 108-109). 
racism, without any factual basis (the finding of the Pithecanthropus erectus by Eugène Dubois would come later). In one of his books, Haeckel included a conjectural genealogy of primates, containing a few expressive neologisms. Of a Protohylobates alalus he made derive obliquely to one side the Asian anthropoids, and to the other the African great apes; and vertically, upwards, the direct ancestors of man, who would be: first the Protohylobates alalus and, between this and Homo sapiens, there would have been a Homo stupidus. From the ascending segment, between stupidus and sapiens, he marked the lateral branches that would have led to the "non-white races" (Haeckel, 1905).

From the end of the 19th century to the 40 s of the 20th century, racist models multiplied in the name of evolutionary science: the racial-evolutionary neurology and the craniometry (Broca, Topinard); the "degenerationist" psychiatry (Morel, Magnan, Lombroso, Down); the evolutionary anthropology (Tylor, Morgan, Frazer, Carlton Coon, William Howells); the eugenic ideologies (Gobineau, Vacher de Lapouges); the "partial neoteny" (Bolk); the racist genetics (Galton, Davenport, Cuénot, William Bateson) (cf. Vieira 1995 for an analysis of these concepts). And, during the years of World War I, the "Piltdown fraud" was perpetrated aiming at falsifying the understanding of human evolution, attempting to place the venerable "ancestor" in England, and attributing to him anatomical features completely opposed to those of the true African ancestors.

One of the rare scientists of this time resisting scientific manipulation was Wallace, the co-founder of the theory of the evolution of species by natural selection. He, who had always accepted that Darwin had primacy in the great discovery; he, who had coined the very word "darwinism", did not follow the master after the publication of The Descent of Man. The fact that the "primitive" (who, in different degrees, he had met in the field, on his expeditions, first to Amazonia and later to the Malay Archipelago) managed to survive in adverse environments, such as the swampy forest, led him to admit that their brain had capacities equal to those of the brain of the civilised man. "In the brain of the lowest savages, and, as far as we know, of the prehistoric races, we have an organ (brain) little inferior in size and complexity to that of the highest type" (Wallace, in Gould, 1985, p. 66). 
This perspective led him to subtract human brain from the selective process - a pathetic mistake that sent him towards a kind of natural theology and set him into theoretic dissent against Darwin, with whom he kept exchanging letters, henceforth assuming his position as unusual ("my own heresy", he would tell him). Such serious misunderstanding contrasts with Wallace's otherwise hyperselectionist views, according to which any morphological or physiological trait in any taxon would be subjected to natural selection ${ }^{8}$. Darwin, in his answers, would send him words of warning, e.g. in a letter written in 1869: "I hope you have not murdered too completely your own and my child". Fatal condescendence to common sense, which falls more on the person of its author - scientist, traveller, collector, anthropologist, socialist and, in his last years, theosofist - than on diverging observations. Again, the a priori prejudice weighs on reason and on the logic of the facts.

During the 20th century, physical anthropology, a science founded by Aleš Hrdlička, still produced several models of racist content. In the $60 \mathrm{~s}$, this science gave place to a multidisciplinary and interdisciplinary research programme, called palaeoanthropology, which investigates the origins and evolution of man, including his genome, morphology, language and behaviour. From the $80 \mathrm{~s}$, with the advent of molecular biology, palaeoanthropologists have demonstrated, based on the comparative study of mitochondrial DNA and the so-called "mitochondrial clock", that Homo sapiens was of African origin (as Darwin had claimed), recent (around 200,000 years before the present day), and had departed from a "genetic bottleneck", from which a limited number of breeding couples with mutant traits had endowed modern humanity with a homogeneous genetic pool, which is how it keeps its unity. The large number of today's mankind has a greater genetic homogeneity than two different populations of wild chimpanzees. As a consequence, the concept of "race" has lost all its operational value in anthropology and anthropological systematics.

8 Hyperselectionism, definitely refuted, claimed that all traits of living beings were the result of a selective process, configuring an entirely adapted nature, something like "the best of worlds" in Leibniz's metaphysics. The Leibnizian idea was also dear to Louis Agassiz, the famous North American scientist, who opposed Darwin's ideas. We know now that the great majority of traits are adaptively neutral (Kimura, 1968). 
Even so, common sense remains open to the fantasy of the existence of "human races". Why is that so? Because, unable to mobilise the effort, the necessary distance and critical capacity to integrate the set of conclusions in the various converging lines of research, common sense indulges in the simplistic view of a racial fracture in mankind. Obsessed by an explanation that suits its prejudice, it ignores or minimises the facts that do not fit. Meanwhile, it takes note of the flagrant phenotypic differences between human beings (e.g. skin colour, average height, straightness of hair, flatness of the ala of the nose) without being willing to accept that they result from the action of a minimal number of genes. On the other hand, common sense takes the cultural and civilizational variations as a reflection of different cognitive capacities. The tendency is deeply rooted in humankind, where many groups call themselves men and consider foreigners sub-human or not human at all.

Wilsonian sociobiology, intrinsically non-racist by the emphasis put on a certain "human condition", has not prevented fantasies such as those expressed by Edward Osborn Wilson himself in his book On Human Nature: "Imagine our moral distress if australopithecine man-apes had survived to the present time, halfway in intelligence between chimpanzees and human beings, forever genetically separated from both, evolving just behind us in language and the higher faculties of reason. What would be our obligation to them? What would the theologians say - or the Marxists, who might see in them the ultimate form of an oppressed class? (...) But even worse, imagine our predicament if we coexisted with a mentally superior human species, say Homo superbus, who regarded us, the minor sibling species Homo sapiens, as the moral problem" (Wilson, 1978, pp. 50-51).

This weighing of moral duties due to a conjectural population of non-human hominins calls for ethical and juridical considerations, such as those that have been raised regarding anthropoids in captivity (laboratories, zoos, circuses, private residences) ${ }^{9}$. As for Homo superbus, he projects perhaps the fantasy of certain intellectuals of placing themselves above the rest of humankind, as if they would form a "race" destined

$9 \quad$ Without forgetting that we are similar, to varying degrees, to all living beings in the biosphere, with whom we share a greater or smaller percentage of genetic material. 
to a superior fate, but unfairly deprived of the privileges they believe they deserve. And after all, this Homo superbus emerges on the horizon of possibilities: at the moment when science has demystified and condemned the concept of "race" inherited from the first evolutionists, genetic engineering gives us the ability to inhibit deleterious genes and to add to human embryos protective genes, able to equip them for longer and healthier lives, but at the price of turning them, eventually, into another subspecies. Here is how the wrongly founded racism of the past shall resurface, perhaps, in the future, this time with a real genetic basis.

In every moment of the history of scientific ideas ${ }^{10}$, and despite the general acceptance of the cumulative character of science, befalls the conviction that we can finally judge critically the scientists of the past, smile at their interpretations and concessions, dear to the dominant ideas of their time and, ultimately, of common sense. Sheer folly: scientists of the future shall weave identical critical comments about us.

\section{References}

Barlow, N., ed. (1958) The Autobiography of Charles Darwin 1809-1882. (With the original omissions restored. Edited and with appendix and notes by his grand-daughter Nora Barlow), London (Collins).

Binswanger, L. (1971) Introduction à l'analyse existentielle, Paris (Minuit), trad. fr. de J. Verdeaux et R. Kuhn.

Blanchard, R. (1885) "L'atavisme chez l'homme", Revue d'anthropologie, vol. X, 8.

Condillac (1984), Traité des sensations, Paris (Fayard).

\footnotetext{
10 Some circles hold the idea that science is never neutral, but dependent on forces which oversee and distort it. In any case, it is the only area of human knowledge about which means of regulation and supervision have been developed, subsumed in the body of epistemology. Of course, the criticism and the foundation of the Enlightenment consist in the opposition to the irrational forces, which influence science in certain points of research, restoring the expedition of its method and the transparency of its findings. The critical project, to borrow the words of Michel Foucault, "était de faire en sorte que la connaissance puisse se faire d'elle-même une idée juste”. (Foucault, 2015, 58).
} 
Dacke, M., Baird, E., Byrne, M., Scholtz, C.H., Warrant, E. J. (2013), "Dung beetles use the Milky Way for orientation", Current Biology, 23 (4): R149-R150.

Darwin, C. (1 859) The Origin of Species by Means of Natural Selection, London: John Murray.

Darwin, C. (1871) The Descent of Man, and Selection in Relation to Sex, London: John Murray.

Darwin, C. (1872) The Expression of the Emotions in Man and Animals, London: John Murray.

Darwin, C. (1988) Charles Darwins's Beagle Diary (R.D. Keynes, ed.). Cambridge: Cambridge University Press.

Dobzhansky, T. (1970) Genetics of the Evolutionary Process. New York: Columbia University Press.

Foucault, M. (2015) Qu'est-ce que la critique? Paris: Vrin.

Gould, S.J. (1980) The Panda's Thumb, New York: W. W. Norton \& Co. Gould, S.J. (1985) "Wallace's Fatal Flaw". In: L. R. Godfrey, ed., What Darwin Began, Newton (Mass.): Allyn \& Bacon, pp. 61-69.

Haeckel, E. (1905) Anthropogenie, Leipzig, 5th ed.: W. Engelmann.

Huxley, J.S. (1942) Evolution. The Modern Synthesis. London: Allen \& Unwin.

Jacob, F. (1970) La logique du vivant. Une histoire de l'hérédité. Paris: NRF/Gallimard.

Jennings, H.S. (1927) Vie et mort, hérédité et évolution, chez les organismes unicellulaires. Paris: Félix Alcan.

Kimura, M. (1968) "Evolutionary rate at the molecular level", Nature, 217 , pp. 624-626.

Kuhn, T. (1970) The Structure of Scientific Revolutions (second version), Chicago: Chicago University Press.

Lamarck, J.P.M. (1907) "Discours d'ouverture (au VII, au X, au XI et 1806)", éd. Giard, Bulletin Scientifique de la France et de la Belgique, T 40, Paris.

Lewontin, R. (1993) The Doctrine of DNA. Biology as Ideology: London: Penguin Books. 
Lorenz, K.Z. (1981) The Foundations of Ethology, New York \& Wien: Springer-Verlag.

Mayr, E. (1976) "Behavior Programs and Evolutionary Strategies". In: E. Mayr, Evolution and the Diversity of Life. Cambridge (Mass.) \& London: Belknap Press, pp. 694-711.

Mayr, E. (1982) The Growth of Biological Thought. Cambridge: Mass. \& London Belknap Press.

Mayr, E. (1991) One Long Argument. Charles Darwin and the Genesis of Modern Evolutionary Thought. London: Penguin Books.

Monod, J. (1970) Le hasard et la nécessité. Essai sur la philosophie naturelle de la biologie modern. Paris: Seuil.

Piattelli-Palmarini, M. (1979) Théories du langage, théories de l'apprentissage, Paris: Seuil.

Rosenthal, R., Rosnow, R.L. (1997) People studying people. Artifacts and ethics in behavioural research. New York: Freeman.

Sacarrão, G.F. (1989) Biologia e Sociedade. Il. Crítica da razão dogmática. Lisboa: Europa-América.

Testut, L. (1904) Traité d'anatomie humaine. Paris: Octave Doin, vol. I, 96.

Thompson, d'A. (1961) On Growth and Form (abridged edition edited by J.T. Bonner), Cambridge: Cambridge University Press.

Thorpe, W.H. (1979) The origins and rise of ethology, the science of the natural behaviour of animals. London: Heinemann.

Uexküll, J. von (1921) Umwelt und Innenleben der Tiere, Berlin.

Vieira, A.B. (1995) "Racismo e teoria", Ethnologia (FCSH da UNL), nova série, $n^{\circ}$ 3-4: 23-38 (Edições Cosmos).

Vieira, A.B. (2005) "Modelos evolutivos e ideologia. O caso Teilhard de Chardin". In: Teilhard de Chardin, evolução e esperança. Antropologia e filosofia, Lisboa, UNL/FCSH (Colibri), pp. 13-28.

Vieira, A.B. (2009-10) "Darwin e as raças humanas", Antropologia Portuguesa (Coimbra, Dep. de Antropologia), n²6-27, pp. 87-96.

Wilson, E.O. (1978) On Human Nature, Cambridge (Mass.): Harvard University Press. 